\title{
業務用電化厨房における置換換気・空調システムに関する研究 STUDY ON DISPLACEMENT VENTILATION SYSTEM IN AN ELECTRICAL COMMERCIAL KITCHEN
}

\author{
近藤靖 史 ${ }^{* 1}$, 荻田俊輔*2, 吉 野 一*3, 藤田 美和子*4 \\ Yasushi KONDO, Shunsuke OGITA, Hajime YOSHINO \\ and Miwako FUJITA
}

\begin{abstract}
Displacement ventilation system (hereafter DV system) is suitable for electrical commercial kitchens because DV system does not disturb thermal plume over electrical cooking equipment. This paper showed experimental results on DV system with a laboratory room in which three cooking equipments i.e. electrical fryer, griddle and range, and an exhaust hood above them were installed. In this paper, the influence of disturbance due to cooking operation on indoor environment, the effects of side panels of an exhaust hood and a ceiling exhaust opening were examined. DV system with ceiling mounted supply openings was also studied. This DV system is compared with general DV system with wall mounted supply openings and local air conditioning system which is very popular in Japanese kitchens.
\end{abstract}

Keywords : Electrical Commercial Kitchen, Displacement Ventilation System, Disturbance, Capture Efficiency of Exhaust Hood, Hood Side Panels, Ceiling Exhaust Opening

業務用電化㕌房, 置換換気, 擾乱, フード捕集率, フード袖壁, 天井排気口

1.はじめに

業務用電化㕑房で使用される調理機器は燃焼排ガスを出さず、そ の多くは熱効率が高いという特長を持ち、檿房内の温熱・空気環境 は良好となるものと期待される。また、業務用厨房における換気・ 空調で消費されるエネルギーは非常に多く ${ }^{1)}$ 、㕌房内の温熱・空気 環境を良好に維持した上で換気量が低減できれば、省エネルギーや 環境負荷の削減となる。しかし、日本では電化欴房の特長を活かし た計画手法の整備が進んでおらず、燃焼式㕌房と同様な換気設計が なされている。この理由の一つとして、電化㕌房では燃燒式㕌房に 比べ調理機器上の熱上昇流が弱い 2)ことにより、厨房内で発生する 空調・換気用の吹出し気流や調理作業者の動きなどによる擾乱の影 響を受けやすいことが挙げられる。すなわち、安易に換気量を減ら すと、熱上昇流が換気・空調気流などによる擾乱の影響を受け、熱 上昇流内に含まれる油煙・熱・臭気などが排気フードで捕集されな い割合が増え、㕌房内温熱・空気環境が悪化する懸念がある。一方、 国内では、業務用電化㕌房の必要換気量として国土交通省監修の建 築設備設計基準 ${ }^{3)}$ に示されている「排気フードの投影面積に $0.3 \mathrm{~m} / \mathrm{s}$ を乗じた值」が採用されることが多い注1)。この必要換気量の全てに 対し温湿度を調整し、㕌房内に導入した場合、空調・換気システム に対する初期費用や運用時のエネルギー消費が多くなる。これに対 し、従来の業務用欴房では、必要換気量の一部に対して温湿度を調 整し、写真 1(a)に示すようなパンカルーバ型吹出口(以降、パンカル 一バと記す)を用いて、調理作業者に気流感を与え、局所的に空調す る方式を採用することが多い。また、温湿度を調整していない空
気(以降、生外気と記す)を直接厨房に導入することとなり、外気取 入口近傍では温熱環境が悪化するだけでなく、食品衛生上の問題に 繋がる懸念がある。また、パンカルーバからの吹出し気流は調理機 器上の熱上昇流に対し擾乱となり、排気フードの捕集率を低下させ、 効率的な換気・空調はできない。例えば、ASHRAE Handbook ${ }^{4)}$ では 業務用欴房に設置する吹出口として、置換換気・空調システム(以降、 置換換気方式と記す)用の吹出口やその他数種類の吹出口が記載さ

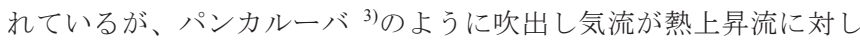
大きな擾乱となり得る吹出口の記載はない。一方、パンカルーバの 採用例が多い日本は欧米とは異なる状況にある。

本研究では、業務用電化厨房における空調吹出し気流による擾乱

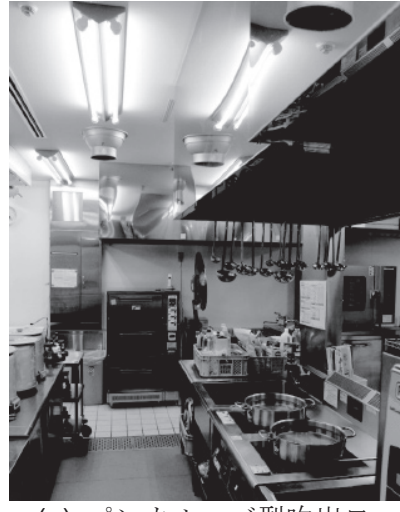

(a) パンカルーバ型吹出口

(国内の厨房内局所空調用)

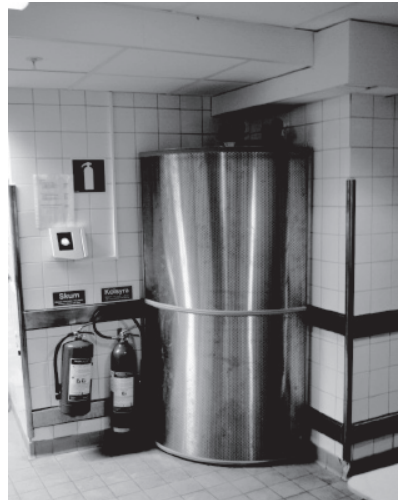

(b) 置換換気用吹出口 (北欧の業務用厨房での事例)
写真 1 業務用厨房内の空調・換気吹出口の例

本論文は，2008年度日本建築学会大会学術講演会(中国)，2009年度日本建築学会大会学術講演会(東北)において発表した論文に基ついて加筆・修正したものである。

*1 東京都市大学工学部建築学科 教授 - 博士 (工学) Department of Architecture, Faculty of Engineering, TOKYO CITY UNIVERSITY, Dr. Eng.

*2 東洋熱工業(侏) 修士(工学)

*3 東洋熱工業(株)

東京都市大学 客員准教授・博士 (工学

*4 中部電力(株)エネルギー応用研究所

Technical Research Institute, TONETS Co., M. Eng.

Technical Research Institute, TONETS Co.

TOKYO CITY UNIVERSITY, Dr. Eng.

Energy Applications Research and Development Center, Chubu Electric Power Co. 
の影響が小さい置換換気方式を検討する。特に、置換換気方式を適用 した場合、換気量を低減した状況においても排気フードの捕集率が高 く維持できるかどうかに着目する。

業務用厨房における置換換気方式の既往の研究としては、Kosonen $ら^{5)}$ や Livchak ら ${ }^{6}$ が実験と CFD 解析により置換換気方式の有効性な どを示している。ただし、これらの研究では調理者の動きに伴う擾乱 の影響は考慮していない。また、Mattsson ら ${ }^{7)}$ や松本ら ${ }^{8}$ はオフィス空 間などの一般環境に置換換気方式を適用した状況を想定し、人の動き に伴う擾乱による換気効率への影響などについて検討している。一方、 業務用厨房における調理者の動きに着目した研究として、百瀬ら ${ }^{9}$ の マネキンを用いた実験がある。また、住宅㕑房における調理者の動き による影響については、坂本ら ${ }^{10)}$ が有人実験と無人実験との比較から 検討している。本研究ではこれらの既往の研究を参考としながら、置 換換気方式を適用した業務用電化厨房において、調理者による擾乱が 存在する状況で、排気フードの捕集率を向上する工夫などを検討し、 より少ない換気量で良好な温熱・空気環境を形成する方法を研究する。 本研究では、先ず調理作業者の動きに伴う擾乱による影響について 2 章で検討する。 2 章では、北欧で定められた業務用厨房内の排気つ ードの捕集性能試験 Nordtest method VVS-088 ${ }^{11)}$ で規定されている擾 乱発生方法と同様に擾乱を与えた。すなわち、幅 $0.5 \mathrm{~m}$ 、高さ $1.0 \mathrm{~m} の$ 板を一定条件で移動させた。次に、調理者による擾乱の影響を軽減し 得る排気フードのフード袖壁の効果を 3 章で検討寸る主 2)。ASHRAE Handbook $^{12)}$ で示されているフード袖壁の形状を参考に 3 種類のフー ド袖壁を用いて実験を行った。さらに、排気フードから溢流した熱や 油煙などを空間上部で排気する天井排気口の効果を 4 章で検討する。 ドイツ技術者協会の厨房換気に関寸るガイドライン(VDI 2052) ${ }^{13)}$ や建 築設備設計基準 ${ }^{3)}$ では、天井に排気口を設け、必要換気量の $10 \%$ 程度 を天井から排気することを推奨している。特に、置換換気方式では温 度成層の形成により熱や污染質が空間上部に滞留する傾向が有り、こ れらを効率的に除去するために、天井排気口の設置は重要であると考 えられ、この効果を実験により検討した。

また、欧米などで適用されている置換換気方式では壁面に大面積の

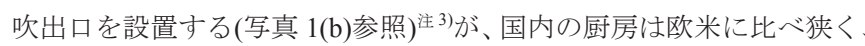
壁面に大面積の吹出口を設置することが通常は難しい。そこで本研究 では、天井面に設置した吹出口による置換換気方式(以降、天井給気 型置換換気方式と記す)の検討を 5 章で行う ${ }^{14)}$, 15)。すなわち、実験に より、天井給気型置換換気方式、壁面から給気する一般的な置換換気 方式(以降、壁面給気型置換換気方式と記す)とパンカルーバを使用し た局所空調方式の 3 方式を比較する。この比較により壁面給気型置換 換気方式と同等の室内温熱・空気環境を天井給気型置換換気方式によ り形成できるかを検討する。また、天井給気型置換換気方式における フード袖壁と天井排気口の有効性を 5 章で再確認する。

\section{2. 調理者による擾乱の影響に関する実験}

\section{1 実験室、擾乱発生装置および実験ケース}

表 1 および図 1 に示すように壁面から給気する置換換気方式とした 碍房実験室 $(4.0 \mathrm{~m} \times 4.0 \mathrm{~m} \times 2.5 \mathrm{mh})$ において実験を行った。実験室の壁 面に接するように IH レンジ、電気グリドル、IH フライヤ(写真 2$) を$ 設置し注 ${ }^{4)}$ 、各点に設置した熱電対により温度を測定する。また、IH レンジ鍋面・電気グリドル鉄板面・IH フライヤ油面の直上(3 箇所)で

表 1 実験室概要(壁面給気型置換換気方式)

\begin{tabular}{|c|c|c|}
\hline 実験室 & \multicolumn{2}{|c|}{$4,000 \mathrm{~mm}(X) \times 4,000 \mathrm{~mm}(Y) \times 2,500 \mathrm{~mm}(\mathrm{Z})$} \\
\hline 床·壁·天井 & 断熱パネル & $\begin{array}{l}\text { 厚さ } 42 \mathrm{~mm} \\
0.49 \mathrm{~W} \cdot \mathrm{m}^{2} / \mathrm{K}\end{array}$ \\
\hline \multirow[t]{3}{*}{ 給·排気口 } & $\begin{array}{l}\text { 吹出口注7) } \\
\text { (SA) }\end{array}$ & $\begin{array}{l}\text { 壁吹出口: } 2 \text { 箇所 } \\
\text { 各 } 1 \text { 方向(側面)に吹出す } \\
\text { 吹出し温度: } 24^{\circ} \mathrm{C} \\
\text { 吹出し開口寸法: } 900 \mathrm{~mm} \times 1,200 \mathrm{~mm} \times 4 \\
\text { 吹出し風速 } \\
\quad: 0.148 \mathrm{~m} / \mathrm{s} \text { (フード面風速 } 0.5 \mathrm{~m} / \mathrm{s} \text { 時) } \\
\quad: 0.088 \mathrm{~m} / \mathrm{s} \text { (フード面風速 } 0.3 \mathrm{~m} / \mathrm{s} \text { 時) } \\
\quad: 0.059 \mathrm{~m} / \mathrm{s} \text { (フード面風速 } 0.2 \mathrm{~m} / \mathrm{s} \text { 時) } \\
\quad \text { 多孔板(パンチング)開ロ率: } 60 \%\end{array}$ \\
\hline & $\begin{array}{c}\text { 排気フード注8) } \\
\text { (EA1) }\end{array}$ & $\begin{array}{l}1,950 \mathrm{~mm}(\mathrm{~W}) \times 650 \mathrm{~mm}(\mathrm{D}) \times 650 \mathrm{~mm}(\mathrm{H}) \\
\text { 張り出し幅 : } 75 \mathrm{~mm}(\mathrm{X} \text { 方向)、50mm(Y 方向 })\end{array}$ \\
\hline & \begin{tabular}{|c|} 
天井排気口 \\
(EA2)
\end{tabular} & VHS $、 350 \mathrm{~mm} \times 350 \mathrm{~mm} 、 90 \mathrm{~m}^{3} / \mathrm{h}$ \\
\hline 照明 & \multicolumn{2}{|c|}{ 蛍光灯 : $40 \mathrm{~W} \times 2$ 本 4 箇所 } \\
\hline
\end{tabular}

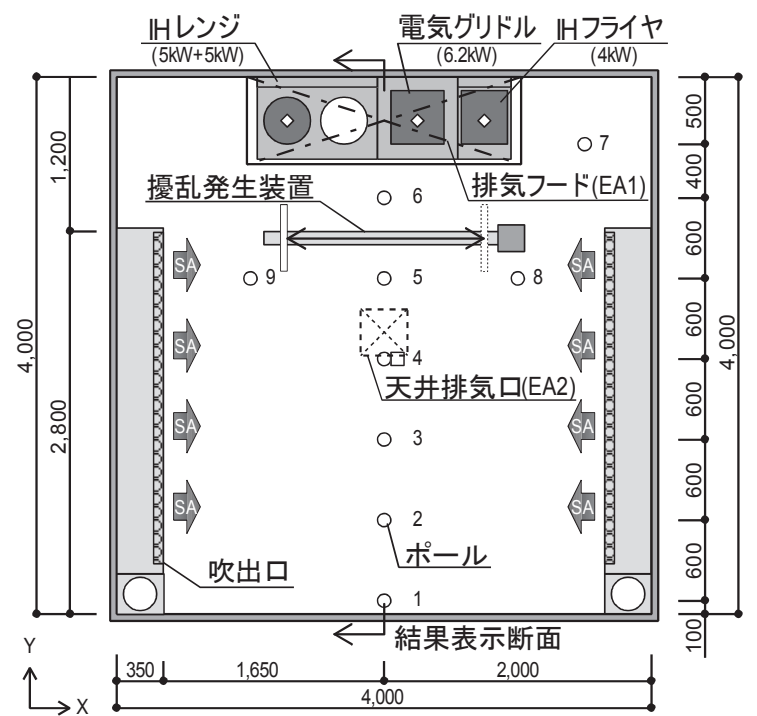

(a) 平面図

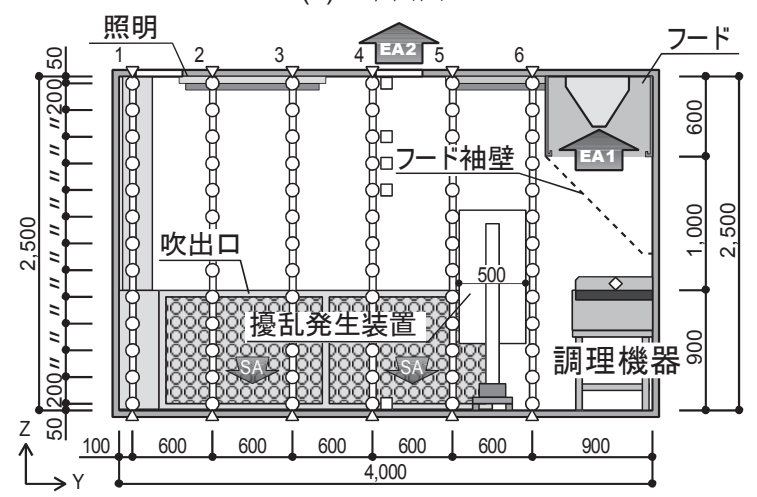

(b) 断面図

凡例 $\mathrm{O}$ :空間温度 $\Delta$ : 表面温度 $\square: \mathrm{SF}_{6}$ 濃度 $\diamond: \mathrm{SF}_{6}$ 発生点

図 1 実験室および測定位置 (壁面給気型置換換気方式)

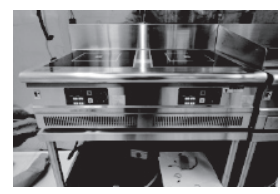

(a) IH レンジ

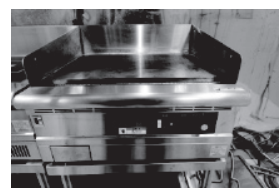

(b) 電気グリドル

写真 2 調理機器など

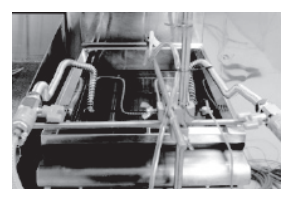

(c) IH フライヤ 単位 $[\mathrm{mm}]$ 
下向きにトレーサガス $\left(\mathrm{SF}_{6}\right)$ を定量発生 $(0.3 \mathrm{~L} / \mathrm{min})$ させ注 5$)$ 、定量ポンプ で測定点の空気をサンプリングし、濃度を測定する。すなわち、トレ 一サガスを調理機器上から発生させた場合、それが室内に溢流する度 合いと室内の濃度は対応寸ると考えられ、本研究では濃度を測定する ことにより、フードの捕集状況を検討している注6。一方、文献 17 に おいて実験により直接捕集率を測定する方法を検討しているが、溢流 した $\mathrm{SF}_{6}$ が再捕集されないように、補助的なフードと天井排気口を設 置する必要があった。このような補助的なフードを設置すると、気流 場や温度場への影響が出るため、本研究では文献 17 で検討した方法 は採用していない。

IH フライヤには約 $11 \mathrm{~L}$ の植物油を投入し設定温度を $180^{\circ} \mathrm{C}$ と、 調理負荷として模擬負荷装置注 ${ }^{9}$ を設置する。電気グリドルは設定温 度を $220^{\circ} \mathrm{C}$ とた。 IH レンジ上には鍋を 2 口あるうちの外側 1 箇所 に設置し、約 $7 \mathrm{~L}$ の水を入れ、設定温度を $80^{\circ} \mathrm{C}$ とした。鍋内の湯量は 定量ポンプによって、一定となるようにした。なお、本研究では調理 機器を壁面に接するように配置しており、この場合熱上昇流は壁面に

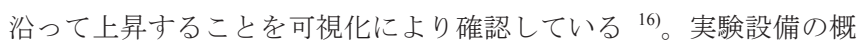
要を表 2 に、測定項目を表 3 に、測定機器を表 4 に示す。

擾乱発生装置は Nordtest method VVS-088 $8^{11)}$ で規定されている擾乱 発生方法と同様に擾乱を与えた。擾乱発生装置を写真 3 に示寸。ただ し、Nordtest method VVS-088 では擾乱発生装置のパネルの移動速度を $0.5 \mathrm{~m} / \mathrm{s}$ としているが、本研究では $0.2 \mathrm{~m} / \mathrm{s}$ とした。これは Nordtest method VVS-088 では実験室の容積を $160 \pm 50 \mathrm{~m}^{3}$ としているが、本研 究での実験室は $40 \mathrm{~m}^{3}$ と小さく、事前の可視化実験で移動速度を $0.5 \mathrm{~m} / \mathrm{s}$ とすると過大な擾乱が観察されたことを考慮している。適切な

表 2 実験設備概要

\begin{tabular}{|c|c|}
\hline 項 目 & 仕 様 \\
\hline $\begin{array}{l}\text { IH レンジ } \\
\text { (卓上タイプ) }\end{array}$ & $\begin{array}{l}\text { 型番 : FIC9060100B(フジマック }) \\
\text { 外形 }[\mathrm{mm}]: 900(\mathrm{~W}) \times 600(\mathrm{D}) \times 265(\mathrm{H}) \\
\text { 質量 : } 56 \mathrm{~kg} \text { 、電源 : } 3 \text { 相 } 200 \mathrm{~V} \\
\text { 総合消費電力 }: 10 \mathrm{~kW} \quad(5.0 \mathrm{~kW}+5.0 \mathrm{~kW})\end{array}$ \\
\hline $\begin{array}{l}\text { 電気グリドル } \\
\text { (卓上タイプ) }\end{array}$ & $\begin{array}{l}\text { 型番 : FEFT60-1TS(フジマック) } \\
\text { 外形 }[\mathrm{mm}]: 600(\mathrm{~W}) \times 600(\mathrm{D}) \times 265(\mathrm{H}) \\
\text { 質量 : } 92 \mathrm{~kg} \text { 、電源 : } 3 \text { 相 } 200 \mathrm{~V} \\
\text { 総合消費電力 }: 6.2 \mathrm{~kW}\end{array}$ \\
\hline $\begin{array}{l}\text { IH フライヤ } \\
\text { (卓上タイプ) }\end{array}$ & $\begin{array}{l}\text { 型番 : FIF114(フジマック }) \\
\text { 外形 }[\mathrm{mm}]: 350(\mathrm{~W}) \times 600(\mathrm{D}) \times 265(\mathrm{H}) \\
\text { 油槽 }[\mathrm{mm}]: 300(\mathrm{~W}) \times 455(\mathrm{D}) \times 115(\mathrm{H}) \\
\text { フライ面積 }[\mathrm{mm}]: 300(\mathrm{~W}) \times 317(\mathrm{D}) \\
\text { 油量 : } 11 \mathrm{~L} \text { 質量 : } 34 \mathrm{~kg} \text { 、電源 : 単相 } 200 \mathrm{~V} \\
\text { 総合消費電力 }: 4.0 \mathrm{~kW}\end{array}$ \\
\hline 鍋 & $\begin{array}{l}\text { 型番: ND-302(ベストコ) } \\
\text { 外形 }[\varphi]: \text { 直径 } 260 \mathrm{~mm} \\
\end{array}$ \\
\hline フード袖壁 & $\begin{array}{l}\text { プラダンシート(半透明、厚み : 3mm) } \\
\text { 外形 }: \text { Case2-L-d : } 160 \times 325 、 30 \text { 度 } \\
\text { Case3-L-d : 285×325、45 度 } \\
\text { Case4-L-d : } 610 \times 650 、 45 \text { 度 }\end{array}$ \\
\hline 空調機 & $\begin{array}{l}\text { 型番 : UAVZ4AR(ダイキン) インバータ制御 } \\
1,800 \mathrm{~m}^{3} / \mathrm{h} \times 400 \mathrm{~Pa} \text { 、電源 }: 3 \text { 相 } 200 \mathrm{~V} 、 0.75 \mathrm{~kW} \\
\text { 冷却能力 : } 16.1 \mathrm{~kW}(\text { 冷却コイル) } \\
\text { 加熱能力 }: 23.2 \mathrm{~kW} \text { (温水コイル) }\end{array}$ \\
\hline 給気ファン & $\begin{array}{l}\text { 型番 : BFS-550TUA1-60 (三菱電機) } \\
2,500 \mathrm{~m}^{3} / \mathrm{h} \times 760 \mathrm{~Pa} \text { 、電源 }: 3 \text { 相 } 200 \mathrm{~V} 、 1.4 \mathrm{~kW}\end{array}$ \\
\hline 排気ファン & $\begin{array}{l}\text { 型番 : BFS-550TUA1-60 (三菱電機) } \\
2,500 \mathrm{~m}^{3} / \mathrm{h} \times 760 \mathrm{~Pa} \text { 、電源 : } 3 \text { 相 } 200 \mathrm{~V} 、 1.4 \mathrm{~kW}\end{array}$ \\
\hline 定量ポンプ & $\begin{array}{l}\text { 型番：Piz8-31-VEC-HWJ(タクミナ) } \\
\text { ソレノイド駆動、流量 : 100ml/min }\end{array}$ \\
\hline 擾乱発生装置 & $\begin{array}{l}\text { 電動スライダ(オリエンタルモータ)仕様 } \\
\text { 型番 : } 1840-\mathrm{NOE} \text { 、重量 : } 36 \mathrm{~kg} \\
\text { モーションコントロールカード(Hivertec) } \\
\text { 制御用ノートPC : Latitude D520(DELL) }\end{array}$ \\
\hline
\end{tabular}

パネルの移動速度については、別途検討が必要であると考えているが、 本研究では実験室の容積を考慮して移動速度を $0.2 \mathrm{~m} / \mathrm{s}$ とした。また、 移動幅は $1.5 \mathrm{~m}$ 注 10$)$ で、調理機器の長手方向の中心より、0.9m 離れた 地点が装置の中心となるように設置する。

実験ケースは表 5 に示寸ように、フード排気量(フード面風速)と擾 乱の有無を組み合わせた 6 ケースである。

\begin{tabular}{|c|c|}
\hline 測定項目 & 測定方法 \\
\hline 空間温度 & 熱電対を用い、1 分毎に計測する。 \\
\hline 風量 & $\begin{array}{l}\text { ピトー管よりダクト内動圧を測定し算出する。 } \\
\text { トレーサガス }\left(\mathrm{SF}_{6}\right) \text { を用い、ダク内濃度を測定し算 } \\
\text { 出する(予備実験時)。 }\end{array}$ \\
\hline 空間内濃度 & トレーサガス $\left(\mathrm{SF}_{6}\right)$ を用い、空間内濃度を測定する。 \\
\hline 吹出し風速 & 熱線式風速計で計測する。 \\
\hline $\begin{array}{c}\text { 可視化 } \\
\text { (調理機器上) }\end{array}$ & $\begin{array}{l}\text { エアロゾルジェネレータを用いて、調理機器(フライ } \\
\text { ヤ)上で発生させる。 }\end{array}$ \\
\hline
\end{tabular}

\begin{tabular}{|c|c|c|}
\hline 測定項目 & 測定機器 & 備考 \\
\hline \multirow{3}{*}{ 温度 } & $\mathrm{K}$ 型熱電対、 $\mathrm{T}$ 型熱電対 & \multirow{2}{*}{ 江藤電気 } \\
\hline & CADAC2 MODEL9220A、9200A & \\
\hline & グローブ球 MT-01GT & 英弘精機 \\
\hline \multirow{2}{*}{ 風量 } & ピトー管(総静圧管) & \multirow{3}{*}{$\begin{array}{c}\text { 山本電機 } \\
\text { 製作所 }\end{array}$} \\
\hline & マノシス圧力伝送器 & \\
\hline \multirow{6}{*}{$\begin{array}{l}\text { 空間内濃度 } \\
\text { •風量 }\end{array}$} & FLOW CONTROL UNIT MC-10A & \\
\hline & リアルタイムガスモニタ Type1313 & \multirow{3}{*}{ INNOVA } \\
\hline & $\begin{array}{l}\text { Multipoint Sampler and Doser } \\
\text { Type } 1303\end{array}$ & \\
\hline & シングルガスモニタ Type3425 & \\
\hline & メドーバキュームポンプ LV-125 & Linicon \\
\hline & $\mathrm{SF}_{6}$ ガスボンベ & 住友精化 \\
\hline 吹出し風速 & 熱線式風速計 クリモマスター6511 & KANOMAX \\
\hline 調理模擬負荷注 9) & \begin{tabular}{|c|} 
流量センサ IR-OPFLOW \\
\end{tabular} & サヤマトレーデ \\
\hline & $\begin{array}{l}\text { 流量表示器 SP562 } \\
\end{array}$ & イング \\
\hline \multirow{5}{*}{ 可視化 } & 微差圧計 $( \pm 100 \mathrm{~Pa})$ & 山本電機製作所 \\
\hline & ポータースモーク PS-2001 & ダイニチ工業 \\
\hline & エアロゾルジェネレータ ATM226 & TOPAS \\
\hline & ビデオカメラ HVR-Z1J & SONY \\
\hline & デジタル 1 眼レフカメラ EOS 30D & CANON \\
\hline
\end{tabular}

表 5 実験ケース(調理者擾乱の有無とフード排気量)

\begin{tabular}{|c|c|c|c|c|}
\hline ケース & フード形状 & $\begin{array}{c}\text { フード排気量 } \\
\text { (フード面風速) }\end{array}$ & 擾乱 & 空調方式 \\
\hline Case 1-H & \multirow{6}{*}{ 通常の箱型 } & \multirow{2}{*}{$\begin{array}{c}2281.5 \mathrm{~m}^{3} / \mathrm{h} \\
(0.5 \mathrm{~m} / \mathrm{s})\end{array}$} & 無 & \multirow{6}{*}{$\begin{array}{l}\text { 壁面給気型 } \\
\text { 置換換気方式 }\end{array}$} \\
\hline Case 1-H-d & & & 有 & \\
\hline Case 1-M & & \multirow{2}{*}{$\begin{array}{c}1368.9 \mathrm{~m}^{3} / \mathrm{h} \\
(0.3 \mathrm{~m} / \mathrm{s})\end{array}$} & $\begin{array}{ll}\text { 無 } \\
\end{array}$ & \\
\hline Case 1-M-d & & & 有 & \\
\hline Case 1-L & & \multirow{2}{*}{$\begin{array}{c}912.6 \mathrm{~m}^{3} / \mathrm{h} \\
(0.2 \mathrm{~m} / \mathrm{s})\end{array}$} & $\begin{array}{l}\text { 無 } \\
\end{array}$ & \\
\hline Case 1-L-d & & & 有 & \\
\hline
\end{tabular}

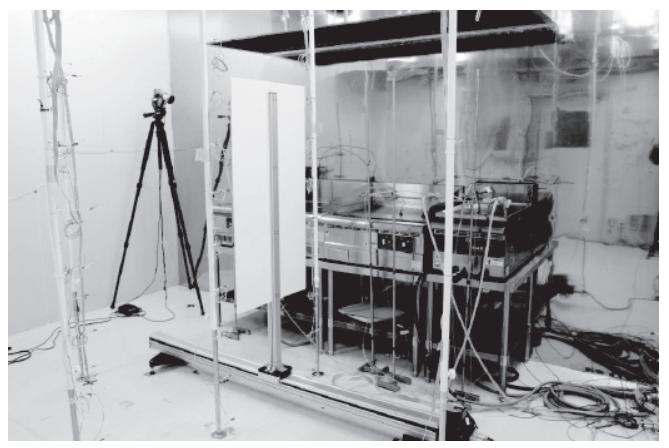

写真 3 擾乱発生装置 


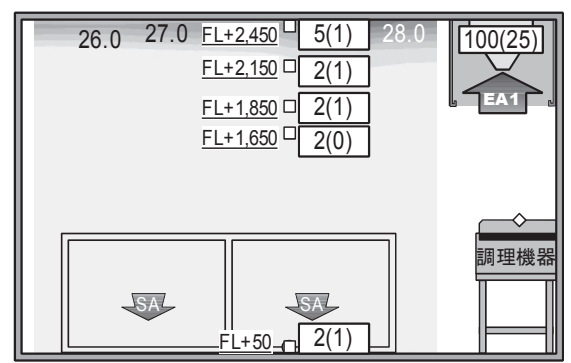

(a) Case 1-H 風量 $2281.5 \mathrm{~m}^{3} / \mathrm{h}$ (面風速 $0.5 \mathrm{~m} / \mathrm{s}$ )

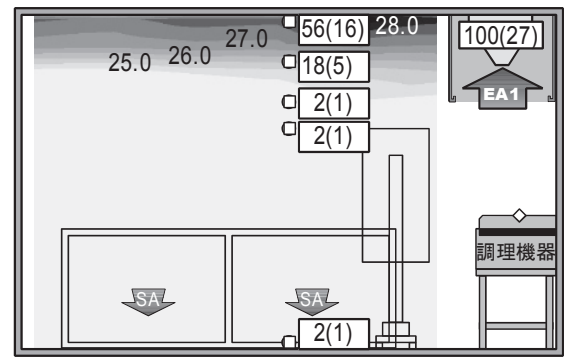

(d) Case 1-H-d 風量 $2281.5 \mathrm{~m}^{3} / \mathrm{h}$ (面風速 $\left.0.5 \mathrm{~m} / \mathrm{s}\right)$

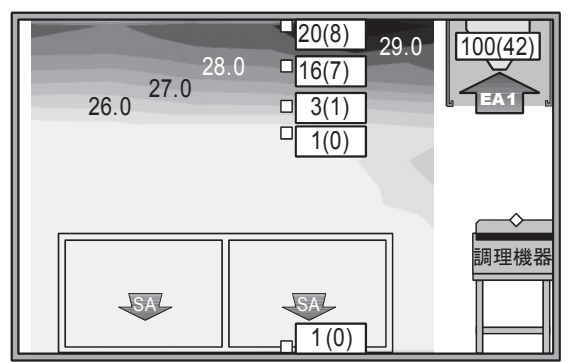

(b) Case 1-M 風量 $1368.9 \mathrm{~m}^{3} / \mathrm{h}$ (面風速 $0.3 \mathrm{~m} / \mathrm{s}$ )

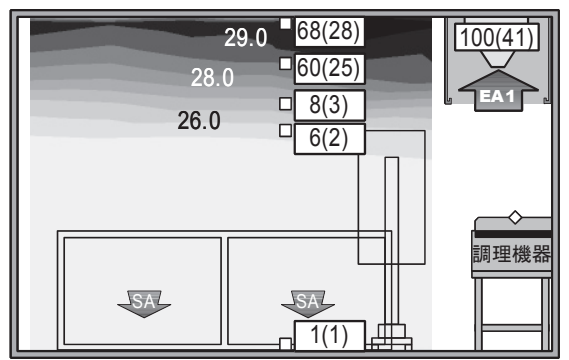

(e) Case 1-M-d 風量 $1368.9 \mathrm{~m}^{3} / \mathrm{h}$ (面風速 $0.3 \mathrm{~m} / \mathrm{s}$ )

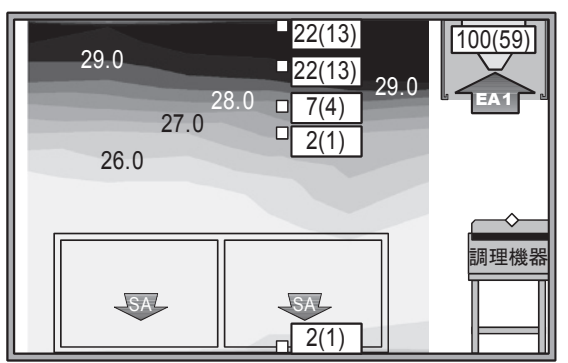

(c) Case 1-L 風量 $912.6 \mathrm{~m}^{3} / \mathrm{h}$ (面風速 $0.2 \mathrm{~m} / \mathrm{s}$ )

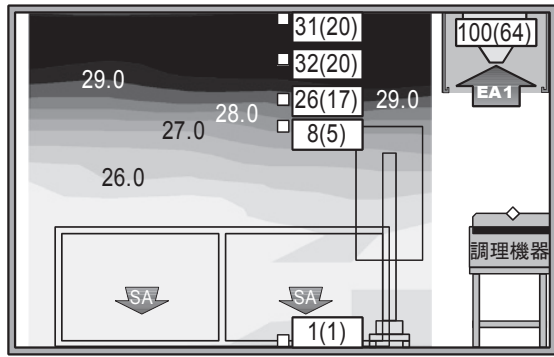

(f) Case 1-L-d 風量 $912.6 \mathrm{~m}^{3} / \mathrm{h}$ (面風速 $0.2 \mathrm{~m} / \mathrm{s}$ )

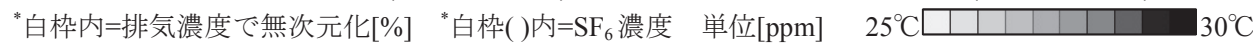

図 2 実験結果(調理者擾乱の有無とフード排気量)

\section{2 実験結果および考察}

実験結果を図 2 に示す。

\section{(1) 温度分布}

各ケースでの比較を容易にするために、空間温度は測定位置(1)～(6) までの 90 点 $(\mathrm{Y}$ 方向 6 点、 $\mathrm{Z}$ 方向 15 点)の測定結果を平均化し、等高 線図として示す。次章以降も同様である。

擾乱無しのケースである Case 1-H、Case 1-M、Case 1-L(図 2(a)〜(c)) では、フード排気量が多いほど空間温度が低い。特に、最も排気量が 多い Case 1-H(フード面風速 $0.5 \mathrm{~m} / \mathrm{s}$ ) では、㕌房全体の温度がほぼ一様 となっていることから換気量はやや過大になっていると考えられる。 これに対して排気量を最も小さくした Case 1-L(フード面風速 $0.2 \mathrm{~m} / \mathrm{s}$ ) では、空間上部で高温となる領域が確認されるが、空間下部の領域 $(\mathrm{FL}+1,650 \mathrm{~mm}$ 以下 $)$ では概衩良好な温度分布が置換換気により形成さ れている。一方、擾乱有りの Case 1-H-d、Case 1-M-d、Case 1-L-d(図 2(d)〜(f))では、擾乱を発生させたことにより、それぞれのケースにつ いて擾乱無しの場合に比べて空間上部は高温となっており、排気フー ドの捕集率が低下していると考えられ、擾乱の影響は無視できない。 ただし、空間下部の FL+1,650mm 以下の領域では大きな差異は見られ ない。

\section{(2) トレーサガス濃度分布}

各ケースでの比較を容易にするために、空間濃度值を排気濃度で無 次元化した值[\%]を示し、濃度測定値[ppm]を併記する。次章以降も同 様である。

擾乱無しの Case 1-H、Case 1-M、Case 1-L(図 2(a)〜(c))では、フー ド排気量の多いケースの方が $\mathrm{SF}_{6}$ の捕集性状が良好である。特に、最 も排気量が多い Case 1-H(フード面風速 $0.5 \mathrm{~m} / \mathrm{s}$ )では、床から天井まで 濃度值に大きな変化はなく、ほぼ完全に捕集できていることがわかる。 これに対して、排気量が最も小さい Case 1-L (フード面風速 $0.2 \mathrm{~m} / \mathrm{s}$ )

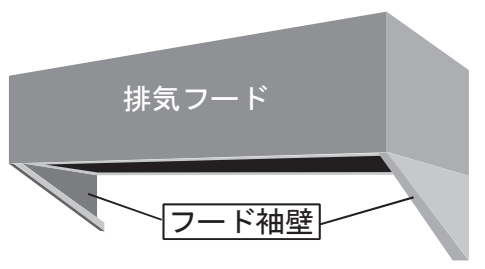

(a) フード袖壁のイメージ図

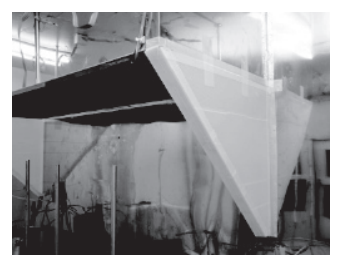

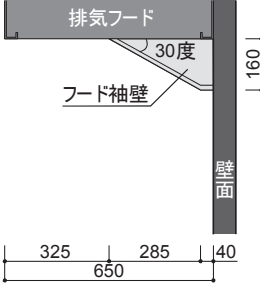

(c) Case 2-L-d(小)

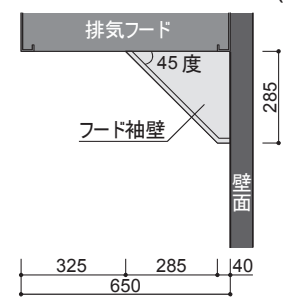

(d) Case 3-L-d(中)

図 3 フード袖壁の形状 (b) フード袖壁(大)

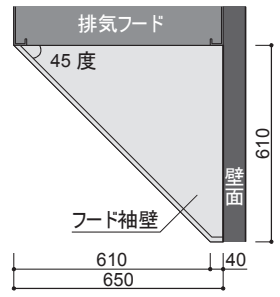

(e) Case 4-L-d(大) 単位 $[\mathrm{mm}]$
表 6 実験ケース(フード袖壁の効果)

\begin{tabular}{|c|c|c|c|c|}
\hline ケース名 & $\begin{array}{c}\text { フード袖壁 } \\
\text { 形状 }\end{array}$ & $\begin{array}{c}\text { フード排気量 } \\
\text { (フード面風速) }\end{array}$ & 擾乱 & 空調方式 \\
\hline Case 2-L-d & 小 & \multirow{3}{*}{$\begin{array}{c}912.6 \mathrm{~m}^{3} / \mathrm{h} \\
(0.2 \mathrm{~m} / \mathrm{s})\end{array}$} & \multirow{3}{*}{ 有 } & \multirow{3}{*}{$\begin{array}{l}\text { 壁面給気型 } \\
\text { 置換換気方式 }\end{array}$} \\
\hline Case 3-L-d & 中 & & & \\
\hline Case 4-L-d & 大 & & & \\
\hline
\end{tabular}

では、空間上部で濃度值が若干高くなっている。しかし、擾乱の無い ケースにおいては FL+1,650mm 以下の濃度分布に大きな差異は見ら れない。

一方、擾乱有りの Case 1-H-d、Case 1-M-d、Case 1-Ld(図 2(d)〜(f)) では、擾乱無しの場合と比べそれぞれのケースにおいて空間上部に おいて高濃度になっており、擾乱の影響が確認できる。ただし、空間 下部の FL+1,650mm 以下の領域では濃度值は低い。なお、別途行った 


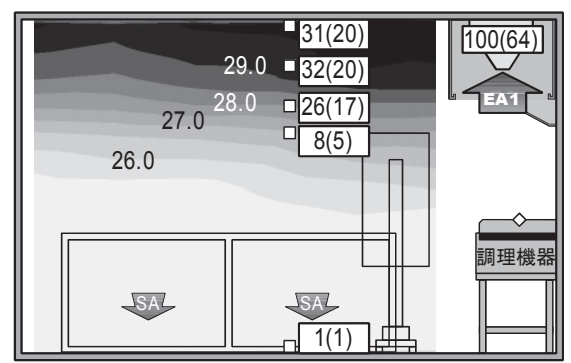

(a) Case 2-L-d (袖壁 : 小)

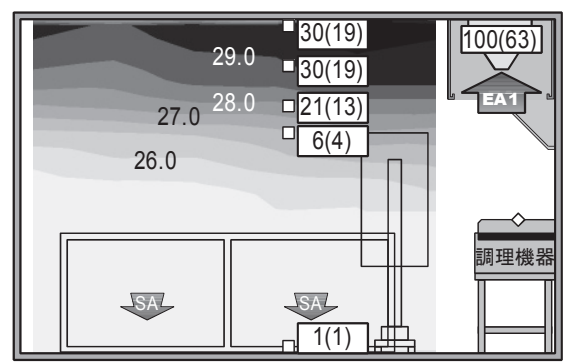

(b) Case 3-L-d (袖壁：中)

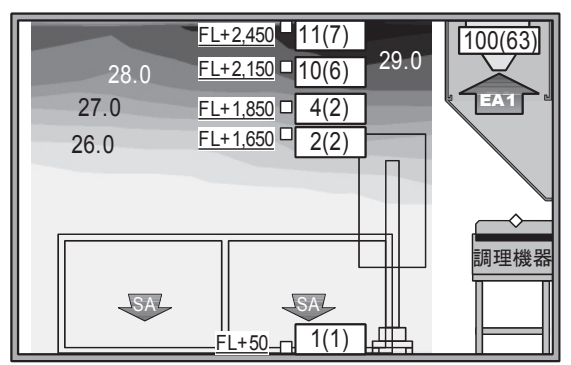

(c) Case 4-L-d (袖壁 : 大)

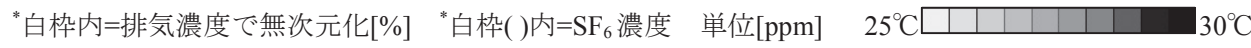

図 4 実験結果(フード袖壁の効果)

可視化実験や CFD 解析 ${ }^{18)}$ により、今回用いた擾乱発生装置では移動 パネルの斜め後方で渦が生じ、これが調理機器上の熱上昇流の主な擾 乱となることが確認されている。また、熱上昇流はパネルの移動と平 行な方向に周期的に摇れ、その摇れ幅が大きく、熱上昇流の一部がフ ードの幅から逸脱する場合にフードの捕集性状が悪くなる状況が観 察されている。

以上のように、置換換気方式の場合、空間下部の温熱・空気環境は 擾乱の有無による差異は小さいが、空間上部では温度やトレーサガス 濃度が高く、排気フードの捕集率向上や空間上部に滞留する熱や污染 空気の除去が重要となる。

\section{3. フード袖壁の効果の検討}

\section{1 フード袖壁の形状および実験ケース}

排気フードに ASHRAE Handbook ${ }^{12)}$ に基づき 3 種類のフード袖壁を 取り付けた実験を行う。フード袖壁の形状を図 3 に示す。なお、本研 究では調理機器を壁面に接するように配置しており、調理機器上の熱

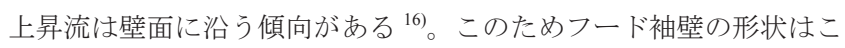
れを考慮し、壁に近くなるほど袖壁の下端が下がるような三角形の形 状としている。実験ケースを表 6 に示す。フード排気量は $912.6 \mathrm{~m}^{3} / \mathrm{h}$ (面 風速 $0.2 \mathrm{~m} / \mathrm{s}$ ) とし、2 章で検討した擾乱発生装置を作動させる。その他 の実験条件は 2 章と同じである。

\section{2 実験結果および考察}

実験結果を図 4 に示寸。

\section{(1) 温度分布}

フード袖壁無しのケースである Case 1-L-d(図 2(f)) と大きさの異な るフード袖壁を付けた Case 2-L-d、Case 3-L-d、Case 4-L-d(図 4(a)〜 (c)) を比較すると、FL+1,650mm 以下の空間下部の温度分布に大きな差異 は見られないが、空間上部の温度はフード袖壁の効果により低くなる 傾向にある。特に、フード袖壁が大きいケースである Case 4-L-d(図 $4(\mathrm{c}))$ では、擾乱が無く、フード排気量が $1368.9 \mathrm{~m}^{3} / \mathrm{h}$ (フード面風速 $0.3 \mathrm{~m} / \mathrm{s}$ )の Case 1-M(図 2(b)) と空間温度が同様であることが確認できる。 (2) トレーサガス濃度分布

Case 4-L-d(図 4(c)) は擾乱が有り、フード排気量が低風量 $\left(912.6 \mathrm{~m}^{3} / \mathrm{h}\right.$ (面風速 $\left.\left.0.2 \mathrm{~m} / \mathrm{s}\right)\right)$ のケースであるが、フード袖壁をつけるこ とによって、擾乱が無く、フード排気量が $1368.9 \mathrm{~m}^{3} / \mathrm{h}$ (面風速 $0.3 \mathrm{~m} / \mathrm{s}$ ) の Case 1-M(図 2(b)) と、空間上部の濃度值 $[\mathrm{ppm}]$ が同等であることが 確認できる。さらに、Case 1-H-d(図 2(d))のような排気量が多いケー スと比べても濃度值が同程度かやや低い。フード袖壁の大きさをやや
表 7 実験ケース(天井排気口の効果)

\begin{tabular}{|c|c|c|c|c|}
\hline ケース & $\begin{array}{c}\text { 給気量 } \\
{\left[\mathrm{m}^{3} / \mathrm{h}\right]}\end{array}$ & $\begin{array}{c}\text { フード排気量 } \\
\text { (フード面風速) }\end{array}$ & $\begin{array}{c}\text { 天井排気量 } \\
{\left[\mathrm{m}^{3} / \mathrm{h}\right]}\end{array}$ & 擾乱 \\
\hline Case 1-L-d & 912.6 & \multirow{2}{*}{$\begin{array}{l}912.6 \mathrm{~m}^{3} / \mathrm{h} \\
(0.2 \mathrm{~m} / \mathrm{s})\end{array}$} & 0 & \multirow{2}{*}{ 有 } \\
\hline Case 1-L-d-c & $1,002.6$ & & 90 & \\
\hline
\end{tabular}

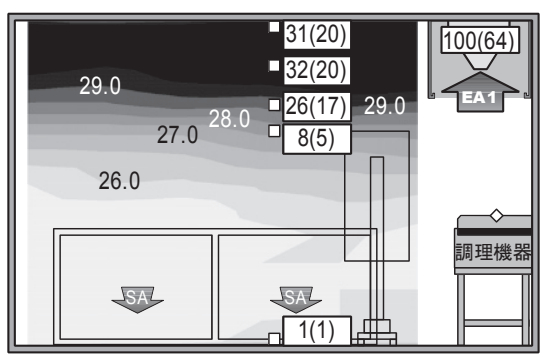

(a) Case 1-L-d(再掲)

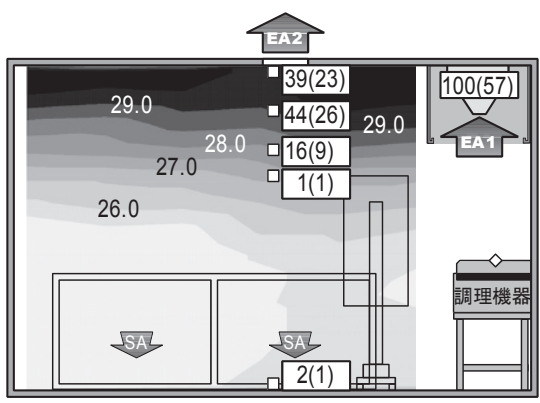

(b) Case 1-L-d-c

*白枠内=排気濃度で無次元化[\%] $\begin{array}{r}* \text { 白枠 }\left(\text { )内 }=\mathrm{SF}_{6} \text { 濃度 単位 }[\mathrm{ppm}]\right. \\ 25^{\circ} \mathrm{C} \square\end{array}$

図 5 実験結果(天井排気口の効果)

小さくしたCase 3-L-d(図4(b)) と、さらに小さくした Case 2-L-d(図4(a)) では、フード袖壁のない場合と比べると濃度が低くなっており、フー ド袖壁の効果が確認できるが、Case 4-L-d ほど顕著ではない。また、 この 2 つのケースの濃度值はほぼ等しい。

このように㕌房での作業性の観点から Case 4-L-d のような大きな フード袖壁を設けることができない場合、空間上部に高温・高濃度の 領域がやや広く残る。この高温・高濃度領域を改善するには、4 章で 示すような天井排気口を設置することが有効であると考えられる。

\section{4. 天井排気口の効果に関する実験}

\section{1 天井排気口および実験ケース}

ドイツ技術者協会の㕌房換気に関するガイドライン(VDI 2052) ${ }^{13) や ~}$ 建築設備設計基淮 ${ }^{3)}$ を参考として、天井に排気口を設け、必要換気量 
の $10 \%$ 程度を天井から排気することを想定する。すなわち、フード の排気量は $912 \mathrm{~m}^{3} / \mathrm{h}$ (フード面風速 $0.2 \mathrm{~m} / \mathrm{s}$ ) とし、天井排気量を約 $90 \mathrm{~m}^{3} / \mathrm{h}$ とし、VHS 型 $(350 \mathrm{~mm} \times 350 \mathrm{~mm})$ の天井排気口を実験室中央天井に設置 した。実験ケースを表 7 に示す。なお、2 章で検討した擾乱発生装置 を作動させる。その他の実験条件は 2 章と同じである。

\section{2 実験結果および考察}

実験結果を図 5 に示寸。

\section{(1) 温度分布}

Case 1-L-d(図 5(a)、再掲)は、空間上部の高温領域は広いが、天井排 気口を設置したケースの Case 1-L-d-c(図 5(b))では、空間上部の高温 領域が小さくなっている。

\section{(2) トレーサガス濃度分布}

Case 1-L-d-c(図 5(b))では、Case 1-L-d よりも空間上部の濃度值は低 いことが確認できる。

以上のように、置換換気方式の場合、温度成層が形成され、空間上 部に熱や污染質が滞留することから、室内の天井に設置する排気口の 効果は大きい。
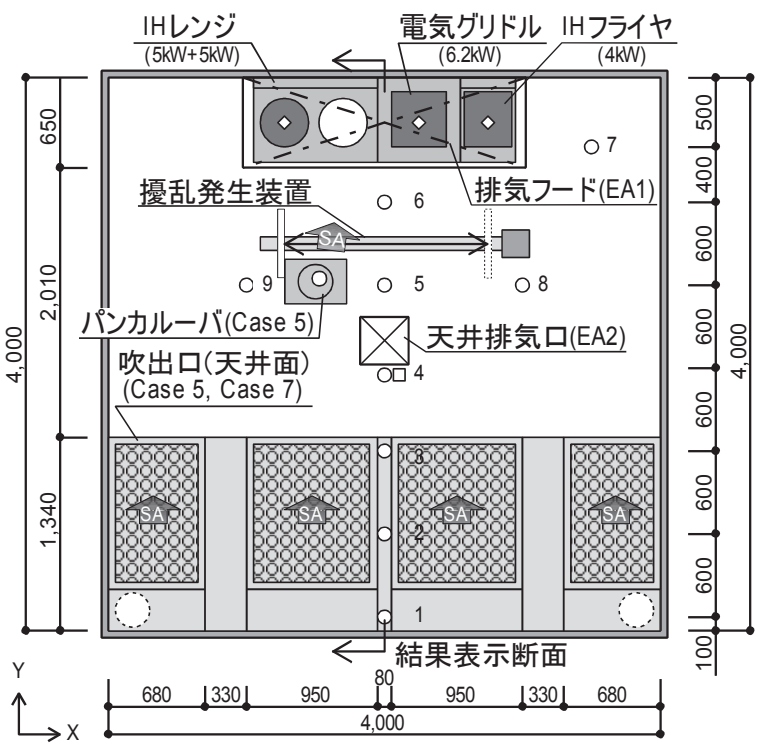

(a) 平面図

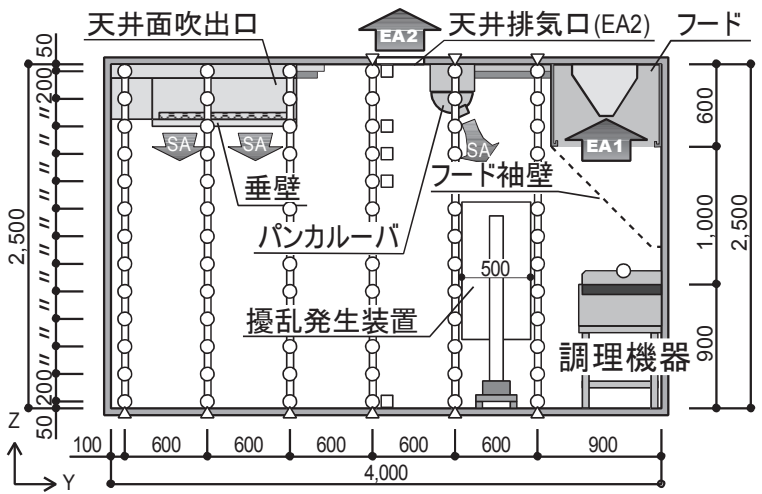

(b) 断面図

凡例 $\mathrm{O}$ :空間温度 $\Delta$ : 表面温度 $\quad \square: \mathrm{SF}_{6}$ 濃度 $\diamond: \mathrm{SF}_{6}$ 発生点 図 6 実験室および測定位置 (天井給気型置換換気方式の検討)

\section{5. 天井給気型置換換気方式に関する実験}

\section{1 実験方法および実験ケース}

天井置換換気方式の有効性を検討するため、壁面給気型置換換気方 式と国内の業務用厨房で使用されるパンカルーバによる局所空調方 式とを実験により比較する。また、既に壁面給気型置換換気方式にお けるフード袖壁と天井排気口の効果は 3 章と 4 章で検討しているが、 ここでは天井給気型置換換気方式におけるこれらの効果を検討する。 5 章で検討する実験室と測定位置を図 6 に、給·排気条件を表 8 に、 実験ケースを表 9 に示す。壁面給気型置換換気方式における給・排気 条件は前章までと同じであり、天井給気型置換換気方式では写真 4 に示すように天井面に多孔板から $0.083 \mathrm{~m} / \mathrm{s} \sim 0.092 \mathrm{~m} / \mathrm{s}$ で給気する。局 所空調方式において、パンカルーバのみでは給気量が足りないため、

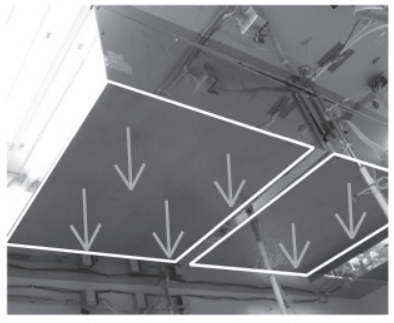

(a) 天井に設置した吹出口

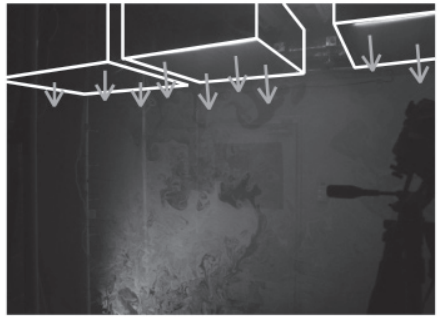

(b) 可視化状況
写真 4 天井給気型置換換気方式の吹出口

表 8 給・排気条件(天井給気型置換換気方式の検討) (1) 吹出口

\begin{tabular}{|c|c|c|}
\hline \multirow{3}{*}{$\begin{array}{c}\text { 吹出口注 7) } \\
\text { (SA) }\end{array}$} & \multirow[b]{2}{*}{ 局所空調方式 } & $\begin{array}{l}\text { パンカルーバ: } 1 \text { 箇所 } \\
\left.\text { 吹出し温度: } 16.0^{\circ} \mathrm{C}^{\mathrm{C}} 11\right) \\
\text { 吹出し開口寸法: } \phi 190 \mathrm{~mm} \\
\text { 給気風量: } 350 \mathrm{~m}^{3} / \mathrm{h} \\
\text { 吹出し風速: } 3.4 \mathrm{~m} / \mathrm{s}\end{array}$ \\
\hline & & $\begin{array}{l}\text { 天井吹出口: } 2 \text { 箇所 } \\
\text { 各 } 1 \text { 方向(下面)方向に吹出す } \\
\left.\text { 吹出し温度: } 28.1^{\circ} \mathrm{C}^{\text {注 }} 11\right) \\
\text { 吹出し開口寸法: } 910 \mathrm{~mm} \times 1,000 \mathrm{~mm} \\
\quad: 610 \mathrm{~mm} \times 1,000 \mathrm{~mm} \\
\text { 給気風量: } 562.6 \mathrm{~m}^{3} / \mathrm{h} \\
\text { 吹出し風速: } 0.1 \mathrm{~m} / \mathrm{s} \\
\text { 多孔板(パンチング)開口率: } 50.9 \%\end{array}$ \\
\hline & $\begin{array}{c}\text { 置換換気方式 } \\
\text { (天井面) }\end{array}$ & $\begin{array}{l}\text { 天井吹出口: } 4 \text { 箇所 } \\
\text { 各 } 1 \text { 方向(下面)方向に吹出す } \\
\text { 吹出し温度: } 23.5^{\circ} \mathrm{C}^{\text {注 } 11)} \\
\text { 吹出し開口寸法: } 910 \mathrm{~mm} \times 1,000 \mathrm{~mm} \times 2 \\
\quad: 610 \mathrm{~mm} \times 1,000 \mathrm{~mm} \times 2 \\
\text { 給気風量: } 912.6 \mathrm{~m}^{3} / \mathrm{h} 、 1,002.6 \mathrm{~m}^{3} / \mathrm{h} \\
\text { 吹出し風速: } 0.083 \mathrm{~m} / \mathrm{s} 、 0.092 \mathrm{~m} / \mathrm{s} \\
\text { 多孔板(パンチング)開口率: } 50.9 \%\end{array}$ \\
\hline \multicolumn{3}{|c|}{ (2) 天井排気口 } \\
\hline 排気口(EA2) & \multicolumn{2}{|c|}{ VHS、 $350 \mathrm{~mm} \times 350 \mathrm{~mm} 、 90 \mathrm{~m}^{3} / \mathrm{h}$} \\
\hline
\end{tabular}

表 9 実験ケース(天井給気型置換換気方式の検討)

\begin{tabular}{|c|c|c|c|c|}
\hline ケース & フード形状 & $\begin{array}{c}\text { フード } \\
\text { 排気量 } \\
\text { (面風速) }\end{array}$ & $\begin{array}{c}\text { 天井 } \\
\text { 排気量 }\end{array}$ & 空調方式 \\
\hline Case 5-L-d & \multirow{3}{*}{ 通常の箱型 } & \multirow{5}{*}{$\begin{array}{c}912.6 \mathrm{~m}^{3} / \mathrm{h} \\
(0.2 \mathrm{~m} / \mathrm{s})\end{array}$} & \multirow{3}{*}{$0 \mathrm{~m}^{3} / \mathrm{h}$} & 局所空調方式 \\
\hline Case 6-L-d & & & & $\begin{array}{l}\text { 壁面給気型 } \\
\text { 置換換気方式 }\end{array}$ \\
\hline Case 7-L-d & & & & \multirow{3}{*}{$\begin{array}{c}\text { 天井給気型 } \\
\text { 置換換気方式 }\end{array}$} \\
\hline Case 7-L-d-s & フード袖壁有 & & $0 \mathrm{~m}^{3} / \mathrm{h}$ & \\
\hline Case 7-L-d-c & 通常の箱型 & & $90 \mathrm{~m}^{3} / \mathrm{h}$ & \\
\hline
\end{tabular}




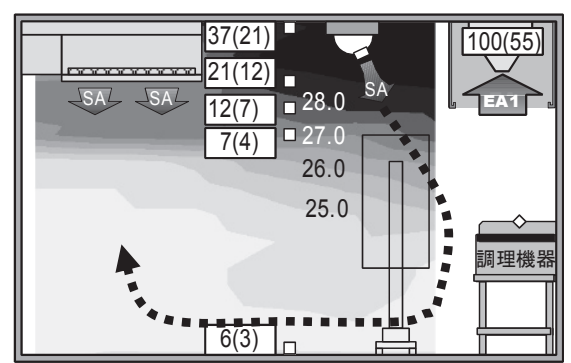

(a) Case 5-L-d

局所空調方式

(パンカルーバ: $350 \mathrm{~m}^{3} / \mathrm{h} 、 16.0^{\circ} \mathrm{C}$ )

(天井吹出口: $562.6 \mathrm{~m}^{3} / \mathrm{h} 、 28.1^{\circ} \mathrm{C}$ )

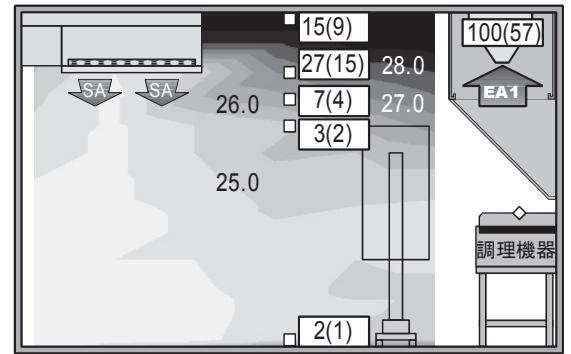

(d) Case 7-L-d-s

天井給気型置換換気方式+フード袖壁 (天井吹出口: $912.6 \mathrm{~m}^{3} / \mathrm{h} 、 23.5^{\circ} \mathrm{C}$ )

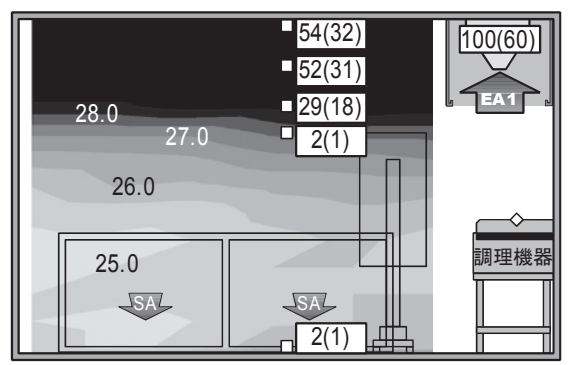

(b) Case 6-L-d

壁面給気型置換換気方式 (壁面吹出口: $912.6 \mathrm{~m}^{3} / \mathrm{h} 、 23.5^{\circ} \mathrm{C}$ )

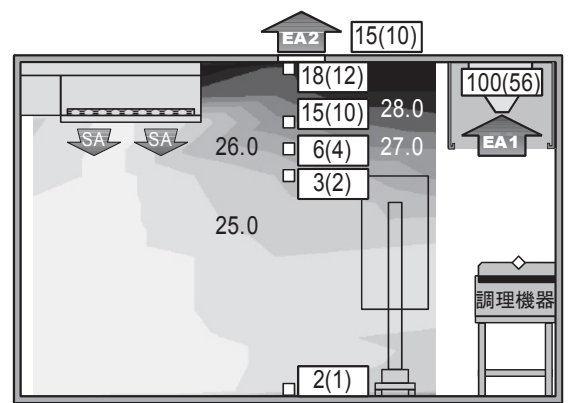

(e) Case 7-L-d-c

天井給気型置換換気方式 + 天井排気口 (天井吹出口: $1,002.6 \mathrm{~m}^{3} / \mathrm{h} 、 23.5^{\circ} \mathrm{C}$ )

図 7 実験結果(天井給気型置換換気方式の検討)

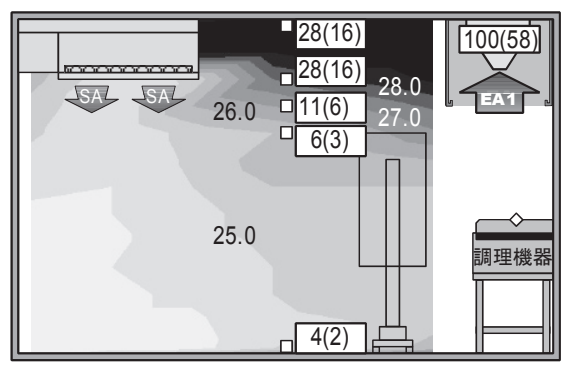

(c) Case 7-L-d

天井給気型置換換気方式 (天井吹出口: $912.6 \mathrm{~m}^{3} / \mathrm{h} 、 23.5^{\circ} \mathrm{C}$ )

*白枠内=排気濃度で無次元化 $[\%]$

*白枠 $\left(\right.$ )内 $=\mathrm{SF}_{6}$ 濃度 $[\mathrm{ppm}]$

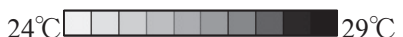

天井給気型置換換気のケースにおける天井給気口を併用寸ることに

より換気量を確保する。フード排気量は $912.6 \mathrm{~m}^{3} / \mathrm{h}$ (面風速 $0.2 \mathrm{~m} / \mathrm{s}$ ) とし、 2 章で検討した擾乱発生装置を作動させる。その他の実験方法などは 前章までと同様である。

\section{2 実験結果および考察}

実験結果を図 7 に示す。

(1) 天井給気型置換換気方式と局所空調方式などとの比較

a) 温度分布

空間下部の温度は、局所空調方式の Case 5-L-d(図 7(a))の方が壁面 給気型置換換気方式の Case 6-L-d(図 7(b)) より約 $0.5^{\circ} \mathrm{C}$ 低い。これは、 Case 5-L-d では擾乱発生装置および空調気流による擾乱の影響で排 気フードから漏れた熱上昇流の影響があるものの、パンカルーバから の $16.0^{\circ} \mathrm{C}$ 低温給気による影響が卓越していたためと考えられる。

Case 6-L-d では温度成層が顕著である。これは、置換換気方式とし た場合、漏出した高温空気と吹出し空気の混合が少ないためであり、 一方、パンカルーバを用いた場合、吹出口付近で漏出した高温空気と 吹出し空気が混合している。壁面給気型置換換気方式の Case 6-L-d(図 7(b)) と天井給気型置換換気方式の Case 7-L-d(図 7(c)) において、空間 下部での温熱環境に大きな差異はない。また、Case 7-L-d においては、 天井付近の高温領域が小さい。これは天井面吹出口から給気された $23.5^{\circ} \mathrm{C}$ 空気が、空間下部だけでなく空間上部の温度分布にも影響し ていると考えられる。

\section{b) トレーサガス濃度分布}

$\mathrm{FL}+1,850 \mathrm{~mm}$ 以上では Case 6-L-d(図 7(b))の方が Case 5-L-d(図 7(a)) に比べ濃度が高い。しかし、空間下部では Case 6-L-d の方が Case 5-L-d に比べ濃度が著しく低い。これは、空間上部に滞留する高濃度空気を パンカルーバの吹出し気流が空間下部へ吹き下ろすためであると考

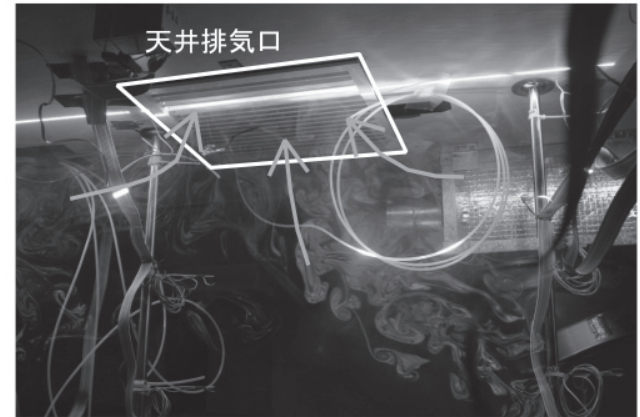

写真 5 天井排気口の可視化状況

えられる。この状沉は可視化実験においても確認している。Case 6-L-d は Case 7-L-d(図 7(c)) に比べて上部の濃度が高く、下部の濃度が低い。 また、Case 6-L-d は作業域と空間上部を境に濃度変化が顕著であるが、 Case 7-L-d は床面から天井面にかけて徐々に濃度が高くなっている。 壁面から給気する場合は、空間上部の高濃度空気との混合が極めて少 ないが、天井から給気を行う場合、空間上部の空気を誘引・拡散させ る可能性があるため、誘引しないような工夫が必要である。本実験で は、天井面からの給気による空間上部の空気の誘引を少なくすること を意図して、給気チャンバーにより天井面から $450 \mathrm{~mm}$ 下げた位置から 吹出している。

\section{(2) 天井給気型置換換気方式におけるフード袖壁の有効性}

Case 7-L-d(図 7(c)))に比ベフード袖壁を付けた Case 7-L-d-s(図 7(d)) は、空間下部での温度には大きな差異は見られないが、フード近傍に おける温度はやや低い。また、Case 7-L-d に比べて天井付近などで卜 レーサガス濃度が低く、フード袖壁の有効性が確認できる。また、調 理機器を壁面に接して配置しているため、熱上昇流は壁面に沿って上 
昇しや寸く、三角形の袖壁の効果がより顕著となる。また、Case 7-L-d-s において、FL+2,450mm に比べ FL+2,050mm での濃度が高い。

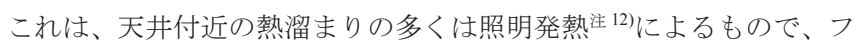
一ドから漏れた熱上昇流は FL $+2,050 \mathrm{~mm}$ 付近で停滞していると考え られる。

\section{(3) 天井給気型置換換気方式における天井排気の有効性}

Case 7-L-d-c(図 7(e))では、Case 7-L-d(図 7(c)) と比べると高温領域が 小さくなっていることや、FL+1,850mm 以上で濃度が低くなっている ことから、空間上部の熱や污染物質の除去を目的とする天井排気口の 有効性が確認できる。その状況は可視化においても確認できている (写真 5)。

\section{6 まとめ}

本研究では、業務用電化厨房に置換換気方式を適用したことを前提 とし、調理者の動きに伴う擾乱の影響、フード袖壁や天井排気口の有 効性を検討し、さらにパンカルーバによる局所空調方式などとの比較 から天井給気型置換換気方式の有効性を検討した。得られた知見を以 下にまとめる。

(1) 調理者の動きなどを模擬した擾乱を与えた場合、空間上部の温 度・トレーサガス濃度は高い。このことから、調理者の動きに伴 う擾乱の影響は無視できないと考えられる。ただし、空間下部の 温度・トレーサガス濃度への擾乱の影響は比較的小さい。

(2) 排気フードにフード袖壁をつけることによって、排気フードの捕 集性状は良好となる。

(3) 置換換気方式では空間上部に熱や污染空気などが滞留する傾向が 有り、天井排気口を設置することにより、これらを除去すること が有効である。

(4) パンカルーバによる局所空調方式と比べ置換換気方式を適用した 場合の方が室内温熱・空気環境が良好である。また、天井給気型置 換換気方式においても壁面給気型置換換気方式とほぼ同等の室内 温熱・空気環境が形成されることを確認した。

(5) 天井給気型置換換気方式においても、フード袖壁と天井排気口の 有効性を確認した。

実験室の容積や形状による実験結果への影響が予想されるため、今 後はさらに大きい空間での検討や、CFD 解析による検討が必要であ ると考えている。

\section{謝辞}

本研究を行なうにあたり、研究当時、武蔵工業大学(現在 東京都市 大学)大学院生 吉田 龍平氏(現在 東京電力)、同 鈴木 陽介氏、同 高 橋 祐樹氏(現在 ダイワハウス工業)、同 川口 明伸氏(現在 NTT フ アシリティーズ)、卒論生 和田 有起氏(現在 TAKEUCHI(株))、同 橋 井 美寛(現在 鹿島建設)からの多大なるご支援を頂きました。また、 実験を行なうにあたり中部電力(株) 倉持 高久氏、ホーコス(株) 藤井 万千雄氏、同 山本 泰成氏、研究当時、武蔵工業大学(現在 東京都市 大学)大学院生 三島 広之氏(現在 鹿島建設)、研究当時 東洋熱工業 (株) 佐々木 秀次氏(現在 東京海洋大学)、東洋熱工業(株) 竹内 仁哉 氏、他武蔵工業大学(現在 東京都市大学)の学生の皆様に多大なるご 協力を頂きました。ここに記して謝意を表します。

\section{本論文に関する既発表論文}

(1) 吉野一, 近藤靖史, 荻田俊輔, 藤田美和子 : 業務用電化厨房の換気・空調に 関する研究 (その 6) 置換換気システムにおけるフード排気量と擾乱の影 響, 日本建築学会大会学術講演梗概集(中国) D-2 環境工学 II, pp.653-654, 2008.9

(2) 荻田俊輔, 近藤靖史, 吉野一, 藤田美和子 : 業務用電化厨房の換気・空調に 関する研究 (その 7) 置換換気システムにおける換気量低減手法としての フード袖壁の有効性, 日本建築学会大会学術講演梗概集(中国) D-2 環境 工学 II , pp.655-656, 2008.9

(3) 藤田美和子, 近藤靖史, 吉野一, 荻田俊輔 : 業務用電化厨房の換気・空調に 関する研究 (その 8) 置換換気システムにおける天井排気の有効性, 日本 建築学会大会学術講演梗概集(中国) D-2 環境工学 II,pp.657-658, 2008.9

(4) 川口明伸, 近藤靖史, 吉野一, 荻田俊輔, 藤田美和子, 山本泰成: 業務用電 化嘚房の換気・空調に関する研究 (その 9) 実験による局所空調方式と置 換換気・空調方式の比較，日本建築学会大会学術講演梗概集(東北) D-2 環 境工学 II , pp.615-616, 2009.8

(5) 近藤靖史, 吉野一, 荻田俊輔, 藤田美和子, 山本泰成, 川口明伸 : 業務用電 化厨房の換気・空調に関する研究 (その 10) 置換換気・空調方式における フード袖壁と天井排気の有効性，日本建築学会大会学術講演梗概集(東北) D-2 環境工学 II, pp.615-616, 2009.8

\section{参考文献}

1) 近藤靖史，長澤康弘，川瀬貴晴，永瀬修，石川登志樹，室田岳志，赤林伸 一: 業務用ちゅう房におけるエネルギー消費量と換気・空調システム, 空 気調和・衛生工学第 75 巻第 9 号, pp.761-770, 2001.9

2) 百瀬敏成, 佐藤隆二, 山中俊夫，甲谷寿史：業務用厨房における外乱気流 がフードの捕集性能に及ぼす影響，日本建築学会計画系論文集第 560 号, pp.15-22, 2002.10

3) 建築設備設計基準(平成 18 年度版) 国土交通省大臣官房官庁営繥部設 備・環境課監修,pp.386-389, 2006

4) 2011 ASHARAE Handbook - HVAC Application, CHAPTER 33 KITCHEN VENTILATION, Diffusers. 33.26, 2011

5) Kosonen, R. and Mustakallio, P.: Analysis of Capture and Containmen Efficiency of a Ventilated Ceiling, International Journal of Ventilation, Volume 2, No.1 pp.33-43, 2003.6

6) Livchak, A., Schrock, D. and Sun, Z.: The Effect of Supply Air System on Kitchen Thermal Environment, ASHRAE annual meeting, OR-05-8-3, 2005.2

7) Mattson, M. and Sandberg, M.: Velocity Field Created by Moving Objects in Rooms, Proc. of $4^{\text {th }}$ International Conference on Air Distribution in Rooms(RoomVent '96), pp.547-554, 1996.7

8) 大庭勇作, 松本博 : 置換換気された室内における人体の移動が室内空気分 布に及ぼす影響に関する研究 その 1 一方向移動モデルを対象とした 実験, 日本建築学会大会学術講演梗概集(北陸) D-2 環境工学 II, pp.813-814, 2002.8

9) 百瀬敏成, 佐藤隆二, 山中俊夫 : 業務用厨房の給排気設計に関する研究 (その 3) フライヤ調理時における横風の影響およびレンジにおける調理 人移動の影響, 空気調和・衛生工学会学術講演会講演論文集, pp.1149-1152, 1999.9

10）坂本淳, 倉㴊隆，奥田篤，相澤芳弘，遠藤智行，近藤靖史：住宅厨房内の温 熱・空気環境に関寸る研究 (その 13) 調理者の行為が捕集率に及ぼす影響 についての検討, 日本建築学会大会学術講演梗概集(九州) D-2 環境工学 II, pp.711-712, 2007.8

11) Nordtest method VVS088: Building Large Scale Kitchen Range Hoods-Hood Efficiency and Pressure Drop, www.nordtest.org, 1990.9

12) 2007 ASHARAE Handbook - HVAC Application, CHAPTER 31 KITCHEN VENTILATION, Hood Side Panels. 31.7, 2007

13) Ventilation equipment for kitchens (VDI 2052), Verein Deutscher Ingenieure, 2006.4

14）荻田俊輔, 近藤靖史, 吉野一, 川瀬貴晴, 平田俊明: 業務用厨房における置 換換気・空調方式に関する研究 (その 1) 天井設置型吹出口による置換換 
気・空調方式の有効性の検討, 日本建築学会環境系論文集, 第 73 巻, 第 628 号, pp.759-766, 2008.6

15) 荻田俊輔，近藤靖史，吉野一，西川向一：業務用厨房における置換換気・ 空調方式に関する研究 (その 2) 従来の換気 - 空調方式と天井吹出し型置 換換気・空調方式の比較，日本建築学会環境系論文集，第 75 巻，第 648 号, pp.179-187, 2010.2

16）鈴木陽介, 近藤靖史, 吉野一, 荻田俊輔, 藤田美和子, 長澤康弘 : 業務用電 化厨房の換気・空調に関する研究 (その 3) 排気フードからの逸流とフー ド形状に関する検討, 日本建築学会大会学術講演梗概集(九州)D-2, 環境 工学 II, pp.729-730, 2007.8

17) 近藤靖史, 吉野一, 荻田俊輔, 藤田美和子 : 業務用電化厨房の換気・空調 に関する研究 (その 5) 排気フードの直接捕集率の測定, 日本建築学会大 会学術講演梗概集(中国)D-2, 環境工学 II, pp.651-652, 2008.9

18）中島裕史，鈴木陽介，近藤靖史：室内における移動物体周辺の気流性状に 関する実験と CFD 解析 (その 1) 実験および CDSM 法と流体占有率を用 いた CFD 解析, 日本建築学会大会学術講演梗概集(北陸)D-2, 環境工学 II, pp.617-618, 2010.9

注

注1）建築設備設計基準 ${ }^{3)}$ によると、電化厨房の必要換気量は排気フードの投影 面積に $0.3 \mathrm{~m} / \mathrm{s}$ を乗じた值と調理機器の定格消費電力量の 30 倍を乗じた值 のどちらか大きい方を採用することとされているが、一般に前者の数值 が大きいことが多い。

注2) 電化厨房設備では、調理機器の加熱方式が燃焼系には該当しないため、 調理機器とフードの離隔距離がある程度緩和できると考えられ、フード 袖壁を設置することを検討した。

注3) 置換換気方式では、壁面下部などに大きな吹出口を設置し、低い風速 $(0.2$ $\sim 0.3 \mathrm{~m} / \mathrm{s}$ ) で空間下部に給気する。

注4) 欧米に比べ日本の厨房は面積が小さく、壁面に接するように調理機器を 配置するレイアウトが多いと考えられるため、本研究ではこのような配 置の厨房を対象として検討を進めた。一方、アイランド型の配置の厨房 においてもフードの捕集性状などが問題となることが多い。これについ ては今後検討する必要があると考えている。

注5) トレーサガス $\left(\mathrm{SF}_{6}\right)$ を放出するにあたり、供給リングなどは使用せずにマ スフローコントローラにて一定量 $(0.3 \mathrm{~L} / \mathrm{min})$ を供給した。

注6) 業務厨房において湿度に関寸る検討が重要であると考えられる。特に、 日本の気候では結露への留意が重要であるが、本研究では湿度の測定は 実施していない。しかし、調理機器上で発生する水蒸気の挙動はトレー サガスを水蒸気と同様に発生させた場合の室内濃度分布により検討でき ると考えられる。トレーサガスでは結露などの現象は再現できないが、 水蒸気の対流(移流)や乱流拡散はトレーサガスのそれとほぼ相似となる と考えられる。なお、結露を含めた湿度に関する検討を別途実施する予 定である。

注7) 吹出口面をフィルタで覆い、均一に空気を供給するようにした。
注8）排気フードの形状・大きさは火災予防の観点と捕集性状の観点の $2 つ に$ より決まると考えられる。火災予防の観点においては、燃焼ガスの拡散 がない電化厨房においても油を扱う場合などは火源となる鍋やフライヤ が存在するため、火源からの距離(離隔距離)はガス厨房と同様とするのが 一般的である。また、捕集性状の観点からは排気フードの張り出し幅(才 一バーハング)が重要であり、これによってフードの大きさが左右される 張り出しの幅が大きいほど、溢流が少なくなる傾向があるが、一方、排 気フード下端の捕集風速(面速)は低くなるという問題が出てくる。本研究 では表 1 に示している通り、フードの前面の張り出し幅は $75 \mathrm{~mm}$ 、側面の 張り出し幅は $50 \mathrm{~mm}$ としている。これは国内の複数の事例を参考として 一般的な張り出し幅を当時検討した結果、採用した寸法である。なお、 適切な張り出し幅については今後検討寸べき項目であると考えている。

注9) 調理負荷として、金属パイプに一定温度・流量 $\left(18.0^{\circ} \mathrm{C} 、 1.70 \mathrm{~L} / \mathrm{min}\right)$ の水を 流した模擬負荷装置をフライヤ油槽内に設置した。

注10) Nordtest method VVS088 $8^{10)}$ ではパネルの移動幅は $1.0 \mathrm{~m}$ であるが、本研究で は調理機器の長手方向にあわせるため $1.5 \mathrm{~m}$ とした。

注11) 設計温度を $25.0^{\circ} \mathrm{C}$ とし、各ケースにおいて給気による投入顕熱量が同じ になるような給気温度とする。局所空調方式の場合、パンカルーバ吹出 し温度 $16.0^{\circ} \mathrm{C}$ 、天井面吹出し温度 $28.1^{\circ} \mathrm{C}$ した。置換換気方式の場合、 吹出し温度を $23.5^{\circ} \mathrm{C}$ に設定した。

注12) Case 7-L-d-s(図 7(d))において、床面から天井面にかけての温度上昇に伴い 濃度も徐々に上昇すると予想したが、FL+2,050mm での濃度が $\mathrm{FL}+2,450 \mathrm{~mm}$ の濃度より高くなった。この現象を確認するため、空間上部 の高温領域の形成がフードから溢流した熱によるものか、天井に設置し た照明の発熱によるかを確認するため、実験室内の照明発熱が無い条件 で実験を行った。

補図 1 に実験結果を示す。天井付近の高温領域はかなり小さくなり、Case 7-L-d-s(図 7(d)) と比べて全体的に室内温度が低い。また、濃度は床面から 天井面にかけて徐々に高くなっている。このことから、Case 7-L-d-s(図 7(d))では照明発熱により天井付近の高温領域が形成され、フードから漏 出した熱上昇流が FL+2,050mm 付近で停滞する状況であったため、 $\mathrm{FL}+2,450 \mathrm{~mm}$ の濃度值が高くならなかったと考えられる。

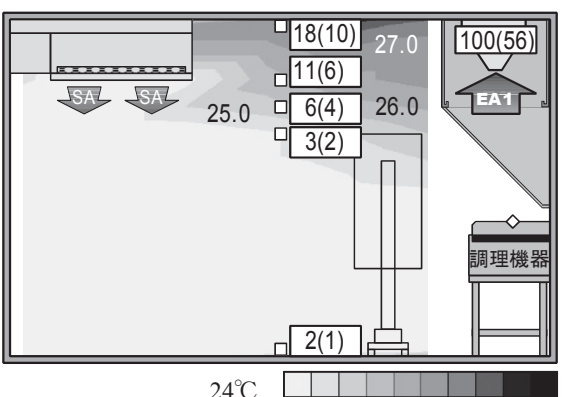

補図 1 照明発熱の影響に関する確認実験 (Case 7-L-d-s(図 7(d))の実験条件で照明発熱無し)

（2011年10月31日原稿受理，2012年 3 月 8 日採用決定） 